\title{
Total kalça artroplastisi sonrası enfeksiyon
}

\section{Infection after total hip arthroplasty}

\author{
Şenol Bekmez, Ömür Çağlar, Bülent Atilla \\ Hacettepe Üniversitesi Tıp Fakültesi, Ortopedi ve Travmatoloji Anabilim Dalı, Ankara
}

\begin{abstract}
Artroplasti sonrası enfeksiyon gelişiminde, hastaya, cerraha, ameliyathane ortamına ve cerrahi tekniğe bağlı faktörler rol oynar. Bu derlemede kalça protezi sonrasında enfeksiyon nedenleri, koruyucu önlemler ve tedavi yöntemleri ele alınacaktır.

Protez enfeksiyonlarında genellikle etken, biyofilm oluşturan mikroorganizmalardır. Tanıda serolojik testler, eklem aspiratında total hücre sayımı ve hücre dağılımı önemli rol oynar. Ancak tanıda altın standart, ameliyat içi örneklemeden gönderilen kültürlerde etkenin izolasyonudur. Enfeksiyonun tipine göre tedavi yaklaşımı değişmektedir. Erken ameliyat sonrası ve akut hematojen enfeksiyonlarda implant korunarak debridman ve parenteral antibiyotik tedavisi uygulanırken, geç kronik enfeksiyonların tedavisinde güncel yaklaşım iki aşamalı revizyon ve antibiyotikli çimento boşluk doldurucu uygulaması ve parenteral antibiyotik tedavisidir. Antibiyotikli çimento uygulamasında antibiyotik salınımını ve lokal bakterisidal etkiyi arttırmak için dikkat edilmesi gereken hususlar vardır. Iki aşamalı revizyonu kaldıramayacak durumda olan hastalarda ise, antibiyotik baskılama tedavisi ve rezeksiyon artroplastisi, tedavi seçeneklerini oluşturmaktadır.
\end{abstract}

Anahtar sözcükler: total kalça replasmanı; kalça protezleri; artroplasti; enfeksiyonlar, protez-ilişkili
Several factors related to patient, surgical techniques and environment are attributed to periprosthetic joint infections. In this review, etiology of the periprosthetic infections and preventive measures, as well as treatment methods will be discussed.

Periprosthetic joint infections are usually caused by biofilm producing microorganisms. Evaluation of the serologic markers, cell count and the differentiation of the joint aspirate are the most reliable diagnostic tests. However definitive diagnosis is made by isolation of the microorganism from the joint. Treatment varies according to the clinical classification of the infection. Preservation of the original implants may be possible in acute hematogenous infection and in immediate postoperative period, whereas joint debridement and parenteral antibiotic treatment is an option for late chronic infections; current treatment is two stage revision where antibiotic loaded cement spacers are used in the interim period followed by a long term parenteral antibiotic administration. There is current debate regarding the dose and effective use of antibiotics impregnated within the cement spacers. In patients that two staged revision is not possible due to comorbidities, lifelong antibiotic supression and resection arthroplasty are regarded as alternative treatment options.

Key words: total hip replacement; hip prosthesis; arthroplasty; infections, prosthesis-related
T otal kalça artroplastisi ameliyatı tüm cerrahi branşlar içerisinde en başarılı ameliyatlardan biri olarak tanımlanmakta, ameliyat sonrasında elde edilen başarının devamında implant tasarımları, biyomateryaller, tespit yöntemleri ve taşıyıcı yüzeyler ile ilgili olarak pek çok yenilik ve iyileşme günümüzde baş döndürücü bir hızla devam etmektedir. Ancak, artroplasti sonrası enfeksiyon gibi hem hasta hem de cerrah açısından yıkımla sonuçlanabilecek bir artsorun riski hala mevcuttur. Total kalça artroplastisi sonrası enfeksiyon, günümüzde halen çözülmesi en zor ve hem hasta hem de hekim için en moral bozucu artsorun olarak varlığını sürdürmekte, birincil artroplastinin 6-7 katına ulaşabilen önemli bir maliyet ve yaklaşık bir yıla kadar uzayabilen işgücü kaybına yol açmaktadır.

Charnley ilk 683 olguluyu içeren kendi serisinde $\% 6,8^{\prime}$ lere varan oranda enfeksiyon bildirmiştir. ${ }^{[1]}$ Bundan sonra Wilson ve arkadaşlarının 100 hastalık serisinde \%11 oranında enfeksiyon rapor edilmiştir. [2] Günümüzde ise uygun hasta seçimi, hastanın ameliyat öncesinde hazırlanması, cerrahi ortamın iyileştirilmesi, profilaktik olarak antibiyotik uygulanması gibi pek çok faktöre dikkat edilmesi sonucu primer cerrahi

- İletişim adresi: Dr. Bülent Atilla, Hacettepe Üniversitesi Tıp Fakültesi, Ortopedi ve Travmatoloji Anabilim Dalı, 06100 Sıhhiye, Ankara Tel: 0312 - 3051209 Faks: 0312 -3100161 e-posta: batilla@hacettepe.edu.tr

- Geliș tarihi: 28 Mart 2013 Kabul tarihi: 12 Temmuz 2013 
sonrasında daha az oranda enfeksiyon görülmektedir. Total kalça artroplastisi sonrası enfeksiyon, kalça revizyon cerrahisi geçiren olguların yaklaşık \%6'sını oluşturmakta olup, aseptik gevşeme ve dislokasyondan sonra üçüncü sırada yer alır. ${ }^{[3]}$

Mayo Kliniğin 30 yıllık artroplasti kayıt sisteminde, 30680 total kalça artroplasti olgusunda \%1,7 enfeksiyon oranı bildirilmiştir. Bu seride birincil olgularda enfeksiyon oranı \%1,3 iken, revizyon olgularında $\% 3,2$ olarak bildirilmiştir. ${ }^{[4]}$

\section{ETIYOLOJi}

Derin enfeksiyon etiyolojisini oluşturan faktörler; hastaya, cerrahi tekniğe, ameliyathane şartlarına ve mikroorganizma özelliklerine göre olmak üzere alt başlıklar olarak ele alınabilir.

Romatoid artrit ve diyabet gibi immün yetmezlik oluşturan sistemik hastalığı bulunan olgularda artroplasti sonrası enfeksiyon oranlarının kontrol grubuna göre daha yüksek olduğu klinik çalışmalarda gösterilmiştir. ${ }^{[5-7]}$ Vücut kitle indeksi (VKi) 35 üzerinde olan hastalarda enfeksiyon yaklaşık 4,2 kat daha fazla olasılıkla olmaktadır. Malnutrisyonun da gecikmiş yara iyileşmesi ve enfeksiyon için predispozan olduğu bilinmektedir. Total lenfosit sayısının $1500 \mathrm{~mm}^{3}$ 'ün altında olması ve serum albumin düzeyinin $3,5 \mathrm{~g} / \mathrm{dl}$ 'nin altında olması kritik değer olarak kabul edilmektedir. ${ }^{[8]}$ Ayrıca yapılan bir çalışmada total kalça artoplastisi uygulanan olgularda serum transferrin düzeyinin $20 \mathrm{mg} /$ dl'nin altında olması gecikmiş yara iyileşmesi ile ilişkili bulunmuştur. ${ }^{[9]}$ Hasta ile ilişkili diğer risk faktörleri arasında obezite, oral steroid kullanımı, psoriasis, idrar yolu enfeksiyonu, uzun süreli ameliyat öncesi hospitalizasyon ve vücutta başka bir enfeksiyon odağının bulunması sayılabilir. ${ }^{[6,10]}$

Aynı eklemde daha önce geçirilmiş cerrahi öyküsünün total kalça artroplastisi sonrası enfeksiyon riskini üç kat artırdığı bildirilmiştir. ${ }^{[11,12]}$ Başka bir çalışmadaysa revizyon kalça artroplastisi olgularında sekiz kat risk artışı bildirilmiştir. ${ }^{[5]}$ Ameliyat sonrası seröz akıntı olan hastalarda derin enfeksiyon gelişme riski dört kat artma olup, özellikle bir haftadan uzun sürenlere debridman önerilmektedir. ${ }^{[13]}$

Ameliyatta kullanılan implant materyalleri ve rekonstrüksiyonun tipinin enfeksiyon riskini etkilediğine dair çalışmalar mevcuttur. Polimetilmetakrilat (PMMA), paslanmaz çelik, kobalt krom ve polietilen, organizmanın bakteriyel hassasiyetini arttırır. Özellikle PMMA kemotaksis, fagositoz ve polimorfonükleer lokositlerin öldürme yetilerini azaltır. Yapısal kemik allogrefti uygulanan 125 olguda, kontrol grubuna göre anlamlı ölçüde yüksek enfeksiyon oranları bildirilmiştir. ${ }^{[14]}$
Ameliyathane ortamı, oda trafiği, profilaktik antibiyotiğin doğru uygulanması, cerrahi alan hazırlığı, laminar akım sistemi kullanımı, cerrahi ekibin giyisileri de enfeksiyon oranlarını etkilemektedir. Ameliyathane oda trafiğini azaltmanın odadaki bakteri yükünü yaklaşık 34 kat azalttığı gösterilmiştir.[15] Cilt hazırlığı ve traşlamanın cerrahiden hemen önce ve ameliyathane ortamında yapılmasının önemi bilinmektedir. Cerrahi alan hazırlığında klorheksidin içeren ajanların povidon iyota göre daha az irritan ve daha etkin olduğu düşünülmektedir.[16]

Cerrahi alan ve cerrah örtünmesinde polipropilen içeren örtülerin standart bez örtülere oranla daha etkin olduğu gösterilmiştir. ${ }^{[17]}$ İyotlu drape uygulamasının enfeksiyon oranını anlamlı derecede azalttığı bilinmektedir. ${ }^{[18]}$ Laminer akım kullanımının, ortamdaki bakteri yükünü \%90 oranında azaltmak ve masada bulunan cerrahi aletlerin kontaminasyonunu engellemek suretiyle total kalça artroplastisi sonrası enfeksiyon oranlarını azalttığını bildiren çalışmalar mevcuttur. ${ }^{[16]}$ Ortamdaki bakteri yükünü azaltmaya yönelik yapılan işlemlere diğer bir örnek, ultraviyole (UV) ışık uygulamasıdır. 2333 hasta içeren bir seride UV uygulaması sonrası enfeksiyon oranlarının kontrol grubuna göre \%3'lerden $\% 0,5$ 'lere düştüğüu gösterilmiştir. ${ }^{[19]}$

Total kalça artroplastisi sonrası derin enfeksiyon oluşumunda cerrahi teknik önemli bir parametredir. Cerrahi esnasında yumuşak doku devitalizasyonu ve hematom oluşumu enfeksiyon oluşumu için davetiye çıkarmaktadır. Uzamış cerrahi süresi enfeksiyon için bir risk faktörüdür. ${ }^{[3]}$ Artroplasti cerrahisinde titiz bir teknik, dikkatli hemostaz ve özenli yara kapatılması esastır.

\section{Enfeksiyondan korunma}

Enfeksiyondan korunmada ilk ve belki de en önemli basamaklardan bir tanesi profilaktik antibiyotik uygulanmasıdır. Patzakis ve ark.yaptıkları çalışmaya göre ameliyat öncesi antibiyotik uygulanması açık kırıklarda enfeksiyon sıklığını etkileyen en önemli parametre olarak göze çarpar. ${ }^{[20]}$ En sık derin enfeksiyona neden olan ajanlar Stafilokokkus aureus ve stafilokokkus epidermidis olduğu için sefazolin veya sefuroksim çoğu elektif ortopedik cerrahide ilk seçilmesi gereken ajanlardır. Vankomisin veya teikoplanin penisilin allerjisi olan veya metilisin dirençli stafilokokkus aureus enfeksiyon sıklığı yüksek olan merkezlerde kullanılabilirler. Antibiyotik profilaksisi insizyon öncesinde $60 \mathrm{dk}$. içinde yapılmalı ve eğer ameliyat içinde kayda değer bir kanama var ise doz tekrarlanmalıdır. AAOS (American Academy of Orthopaedic Surgeons) sefazolinin her 2-5 saat; vankomisinin de 6-12 saatte bir tekrarlanmasını 
önermektedir. Antibiyotik profilaksisinin 24 saati aşmasının ek bir yarar sağlamadığı gösterilmiştir. ${ }^{[21]}$

\section{Mikrobiyoloji}

Total kalça artroplastisi sonrası enfeksiyona neden olabilen patojenler gram pozitif ve negatif bakterileri içermektedir. Enfeksiyon kliniği bulunan bazı olgularda etkeni izole etmek her zaman mümkün olmayabilir. Sorumlu etkeni kültürde üretmedeki zorluklar ve ampirik oral antibiyotik tedavisinin etkeni baskılaması başta gelen sebepler arasında sayılabilir. En sık izole edilen patojenler stafilokokkus aureus ve stafilokokkus epidermidis'tir. Son yıllarda metisiline dirençli stafilokokkus aureus ve vankomisine dirençli enterokok gibi birden çok antibiyotiğe dirençli enfeksiyonlar artış göstermektedir. Hacettepe'de yapılan bir çalışmada 2009-2012 tarihleri arasında ICD tanı kodlama sistemine göre T84.5 (internal ortopedik cihazların enfeksiyonu) tanı koduyla yatırılan hastalardan aspirasyon veya derin doku örneklemesi sonucunda üreme olanlar stoklandı. Bu stoklardan 19 koagülaz negatif stafilokok, 11 Staphylococcus aureus suşu, 6 Acinetobacter suşu, 2 Escherichia coli suşu, 1 Citrobacter suşu ve 1 Morganella morganii suşu tespit edildi. ${ }^{[22]}$

Yapılan deneysel çalışmalarda akrilik çimento, paslanmaz çelik, kobalt-krom alaşımlar ve polietilen implantların enfeksiyonlara karşı duyarlılığı artırdığı gösterilmiştir. ${ }^{[23]}$ Protezin kendisi bakteri kolonizasyonu için yabancı cisim görevi görür. Patojen bakteriler bu yabancı cisimlere fiziksel ve kimyasal kuvvetler ile yüzeylerinde bulunan reseptör görevi gören proteinler aracılığıla yapışır. ${ }^{[24]}$ Protez enfeksiyonu meydana gelmesi için bakteri kolonizasyonu mutlak gerekli olup, yeterli değildir. Metaller vücut içine implante edildikleri zaman başarılı bir biyointegrasyon için konak hücrelerinin implant üzerinde kolonizasyonu gerekir. Bu aynı zamanda bakteriyel kolonizasyonu da önleyecektir. Bakteri kolonizasyonu ve birlikte başlayan doku integrasyonu arasında bir yarış meydana gelir. Eğer bakteriyel kolonizasyon ön planda ise immün sistemi baskılayan ve bakteriyel çoğalmayı kolaylaştıran, mikrozon adı verilen kondüktif bir ortam oluşur. Bu ortamda bakteriler metabolizmalarını yavaşlatarak 'slime tabakası' adı verilen, birikmiş bakteriyel kütle ve mukopolisakkarit yapıdaki glikokaliks biyofilmden oluşan koruyucu bir tabaka üretmeye başlar. Genellikle glikokaliks yapısında olan biyofilm bakterilerin beslenme şekilleri, antikor dirençlerini ve antibiyotik direncini arttırarak enfeksiyonun yerleşmesini sağlar. İmplant kaynaklı enfeksiyonların \%76'sında bakteriyel glikokaliks biyofilm oluşur. Biyofilm bir kez oluştuktan sonra bu tabaka implanttan uzaklaştırılmadan enfeksiyonun tedavisi başarılı olmaz. Enfeksiyonun kronikleşmesi ile orantılı olsa da 72 saat içinde bile biyofilm oluşumu gözlenebilir. Bu şekilde antibiyotik ve immün sisteme karşı direnç kazanılır. ${ }^{25,26]}$

\section{SINIFLANDIRMA}

Bugün için tedavide yön gösterici özelliğinden dolayı Tsukayama sınıflandırılması sıklıkla kullanılmaktadır. Buna göre hastalar intraoperatif kültür pozitifliği, erken ameliyat sonrası enfeksiyon, kronik geç enfeksiyon ve akut hematojen enfeksiyon olarak 4 grupta incelenirler (Tablo 1). ${ }^{[27]}$ Eski serilerde yara kontaminasyonuna bağı akut enfeksiyonlar daha sık olarak bildirilmekte olup, antibiyotik profilaksisi, antibiyotikli çimento kullanılması, cerrahi teknik ve ameliyathane ortamındaki gelişmeler nedeniyle günümüzde kronik enfeksiyonlar daha sık görülmektedir. ${ }^{[28,29]}$

\section{TANI}

Protez enfeksiyonlarının tanısında ilk önce öyküde bir kronik hastalığa eğilim olup olmadığı sorgulanmalıdır. Fizik muayenede sıvı birikimi, ısı artışı, hassasiyet ve drene sinus varlığı enfeksiyon için anlamlı bulgular olmakla beraber, hemen her hastada görülen semptom ağrıdır. ${ }^{[30]}$

Radyografik bulgular non-spesifiktir. En sık görülen bulgu ilerleyici prostetik gevşeme olup, aseptik gevşemeden ayrılması mümkün değildir. Diğer röntgen bulguları, periosteal yeni kemik oluşumu ve ektopik kemik oluşumudur.

Tablo 1. Protez enfeksiyonlarının sınıflandırması

Tip 1 Aseptik gevşeme için yapılan revizyon cerrahisi sırasında ameliyat içi kültür pozitifliği.
Tip 2 Akut enfeksiyon - cerrahi sonrası ilk dört hafta içerisinde başlayan.
Ameliyat içi kontaminasyonla ilişkili.
2a: Eklem kapsülünden daha yüzeyel.
2b: Eklem kapsülünden daha derin.

Tip 3 Akut hematojen enfeksiyon - cerrahi sonrası dördüncü haftadan daha geç başlangıçlı.

Tip 4 Geç kronik enfeksiyon - dördüncü haftadan daha geç başlangıçlı. Sinüs oluşumu ile birlikte. 
Protez enfeksiyonlarında tam kan sayımında total beyaz küre sayısı non-spesifik olarak artmakla birlikte, her olguda bu artış görülmeyebilir. ${ }^{[31]}$

Hematolojik testler arasında geleneksel olarak en sık kullanılanlar eritrosit sedimentasyon hızı (ESH) ve C-reaktif protein düzeyi (CRP)'dir. ESH'nin \%60 sensitivitesi ve $\% 65$ spesifisitesi mevcut olup, tanı koymada tek başına yetersizdir. ${ }^{[32]}$

Yapılan bir çalışmada, ağrı nedeniyle revizyon planlanan 151 artroplasti olgusu prospektif olarak incelenmiş; ESH hızı 22,5 mm/s, CRP değeri 13,5 mg/L sınır değer alındığında, enfeksiyon tanısının konmasında $\mathrm{ESH}$ ve CRP düzeylerinin birlikte değerlendirilmesinin etkin bir yöntem olduğu belirtilmiştir. ${ }^{[33]}$ Protez enfeksiyonu tanısında tanımlanmış diğer serolojik belirteç arayışlarına prokalsitonin ve interlökin- 6 örnek olarak verilebilir. Prokalsitonin bir akut faz reaktanı olup, yüksek spesifisitesine rağmen, düşük sensitiviteye sahip bir belirteçtir. ${ }^{[34]}$ Interlökin-6 (IL-6) da monositmakrofajlarca üretilen bir akut faz reaktanıdır. IL-6 düzeyinin $10 \mathrm{pg} / \mathrm{ml}$ 'den yüksek olmasının diğer belirteçlerden daha anlamlı olduğu, ayrıca ameliyat sonrası ikinci gün normal değerlere döndüğü bildirilmiştir. ${ }^{[35]}$

Artroplasti sonrası enfeksiyon tanısında teknesyum 99m sintigrafisi yaygın olarak kullanılmıştır, ancak bulgular non-spesifiktir. Teknesyum 99m sintigrafisi kemikteki yüksek metabolik aktiviteyi göstermekle birlikte kırık ve remodeling gibi diğer durumları ayırt edemez. [32] Indium-111 sintigrafisi lökositleri işaretleyerek inflamasyonu gösterdiğinden yüksek duyarlılık ve özgüllük sağlar. ${ }^{[36]} 92$ revizyon kalça olgusundan oluşan bir seride ise teknesyum $99 \mathrm{~m}$ sulfur kolloid taraması ve Indium-111 sintigrafisinin kombine olarak uygulanması sonrası \%100 duyarlılık ve \%97 özgüllük bildirilmiştir. ${ }^{[37]}$

Kalça artroplastisi sonrası enfeksiyon tanısında pozitron emisyon tomografisi (PET)'nin umut vaat eden sonuçları bildirilmiştir. Son yapılan çalışmalarda FDG PET (pozitron emisyon tomografisi) ile septik veya aseptik kalça ağrısı nedenleri araştıııldığında PET ile periprostetik enfeksiyon tanısı \%85 duyarlılık ve \%93 özgüllük ile konabilmektedir. 3 fazlı kemik sintigrafisine göre daha etkin olduğu bildirilmiştir. ${ }^{[38]}$

Kalça artroplastisi sonrası enfeksiyon tanısında bir sonraki basamak eklem aspirasyonudur. Ağrı şikayetiyle gelen, ESH ve CRP yüksekliği bulunan bir hastada steril şartlarda eklem ponksiyonu yapılır. Hasta, eğer kullanıyorsa, en az 3 hafta önceden antibiyotik tedavisini sonlandırmış olmalıdır. Elde edilen sıvıda gram boyama, kültür ve hücre sayımı çalışmaları yapılabilir.

Artroplasti sonrası enfeksiyon tanısında gram boyama bir tanısal test olarak başarısızdır. 169 kalça revizyon olgusundan oluşan bir seride, enfekte olguların hiçbirisinde gram boyamanın pozitif çıkmadığı bildirilmiştir. ${ }^{[39]}$ Enfeksiyon şüphesi olan ve revizyon planlanan olgularda preoperatif aspirasyon materyalinden kültür gönderilmesi konusunda yapılan çalışmalarda \%60'larda duyarlılık oranları bildirilmiştir. ${ }^{[40]}$ Ayrıca tekrarlayan aspirasyonlarda duyarlıı̆ıın yükseldiği belirtilmektedir. Bu nedenle aspirasyon materyalinden kültür bir tarama testi olarak zayıf olsa da, semptomatik hastalarda destekleyici test olarak önemli bir yer teşkil etmektedir. Eğer kullanılıyorsa, antibiyotik kesilmesini takiben en az 3 hafta sonra yapılmalıdır.

Aspirasyon sıvısında hücre sayımı ve hücre dağılımı günümüzde artroplasti sonrası enfeksiyon tanısında çok önemli bir yere sahiptir. Literatürde geçmişten bu güne yapılan çalışmalarda hücre sayımı ve dağııımı konusunda birçok farklı eşik değerleri tanımlanmıştır. Biz kendi pratiğimizde, Della Valle, Schinsky ve arkadaşlarının yaptığı, 220 revizyon kalça olgusunu içeren çalışmanın ortaya koyduğu değerleri baz alarak değerlendirme yapıyoruz. ${ }^{[41]}$ Buna göre ESH ve CRP değerleri dikkate alınmadan yapılan değerlendirmede, total hücre sayısı 4200/ml'den fazla ve hücre dağılımı \%80'den fazla PMNL değerleri optimal eşik değerler olarak kabul edilmektedir. ESH ve CRP değerlerinin yüksekliği ile kombine edildiğinde ise en üst sınır $>3000 / \mathrm{ml}$ olarak alınmalıdır. Ayrıca bu çalışmada ESH $<30 \mathrm{~mm} / \mathrm{s}$ ve $C R P<10 \mathrm{~g} / \mathrm{dl}$ olan hiçbir olguda protez enfeksiyonu saptanmamıştır. ${ }^{[41]}$

Enfeksiyon ön tanısı konularak revizyon planlanan ancak eklem aspirasyonu sonrasında tanısı kesinleştirilemeyen veya kültürde etken izole edilemeyen durumlarda, ameliyat içi frozen değerlendirmesi cerraha karar vermede son derece yardımcı bir tanısal yöntemdir. Frozen materyali eklem kapsülü ve periprostetik membranın birden çok bölgesinden alınmalıdır. Frozen kesitlerinde belirgin aktif inflamasyon görülmesi enfeksiyon açısından tanı koydurucu olup, aktif inflamasyon görülmemesi ise enfeksiyonu ekarte eder. Ancak ne yazık ki, her olguda tablo bu kadar aşikar olmayıp, aktif inflamasyon olmadan düşük dereceli nötrofil/lenfosit/ plazma hücre infiltrasyonları saptanabilir. Borderline (sınır) olarak tariflenen bu olgularda çeşitli yazarlar tarafindan farklı tanısal kriterler tanımlanmıştır. ${ }^{[22-45]}$

Kalça artroplastisi sonrası enfeksiyon tanısında altın standart, revizyon cerrahisi sırasında alınan sıvı/doku kültürüdür. Yalancı pozitif veya yalancı negatif sonuçları engellemek için bazı kurallara uymak zorunludur. Buna göre ameliyat öncesi dönemde en az 2 hafta önce antibiyotikler kesilmeli, örnekleme yapılana kadar hastaya profilaktik antibiyotik verilmemeli, ameliyat içi örnekleme sırasında kontaminasyondan kaçınılmalı, örnekler protezin çeşitli bölgelerinden bistüri ile keskin diseksiyonla alınmalıdır. 
Ameliyat içi değerlendirmede tanısal test olarak tanımlanmış ve geleceği olan metodlar arasında PCR ile bakteriyel genin tespiti ve endotoksin incelemesi sayılabilir.

\section{TEDAVi}

Total kalça artroplastisi sonrası enfekte olan hastalarda geçmişten günümüze bir çok farklı tedavi yöntemi uygulanmıştır. Antibiyotik supresyonu, rezeksiyon artroplastisi veya artrodez gibi seçenekler günümüzde sadece genel durumu revizyon cerrahisi için uygun olmayan hastalarda uygulanmaktadır.

Akut ameliyat sonrası enfeksiyonlarda (Tip 2) ve akut hematojen enfeksiyonlarda (Tip 3), protez tespiti sağlam ise protezi koruyarak debridman ve takibinde parenteral antibiyotik tedavisi uygulanmaktadır. ${ }^{[46]}$ İrrigasyon, debridman ve değişebilen parçaların değiştirilerek protezin korunması ve takiben 6 hafta i.v antibiyotik tedavisi tipik olarak akut hastalıkta endike olmaktadır. Bu hastalarda protez tespiti sağlam olmalı ve izole edilen bakteri antibiyotiklere hassas gram pozitif bakteri olmalıdır. Erken ameliyat sonrası (ilk dört hafta) ve akut hemotojen enfeksiyon tedavisinde kullanılabilir. Bu yaklaşım için semptomların süresinin 3-4 haftadan az olması ve önceki cerrahilerden kalma geniş skar olmaması yazarlar tarafından özellikle ön koşul olarak belirtilmiştir. ${ }^{[46]}$ Tsukayama erken ameliyat sonrası hastalıkta $\% 74$, akut hematojen enfeksiyonda ise $\% 50$ başarı bildirmiştir. ${ }^{[47]}$

Revizyon cerrahisi sırasında ameliyat içi alınan örneklerde kültür pozitifliği bulunan olgularda (Tip 4), etken bakterinin duyarlı olduğu bir antibiyotikle parenteral tedavi uygulanmalıdır.

Geç kronik enfeksiyonlarda ise (Tip 4) güncel yaklaşım; revizyon tedavisi şeklindedir. Debridman sonrasında tek aşamalı olarak aynı seansta veya iki aşamalı olarak yapılabilir. Etkenin izole edildiği, genel durumu iyi olan bazı seçilmiş olgularda, antibiyotikli çimento ile tespit uygulanan tek aşamalı revizyon cerrahisi ile başarılı sonuçlar bildirilmiştir. Bugün için çok sınırlı merkezlerde uygulanmaktadır. Tek aşamalı revizyon cerrahisi için aranan kriterler Tablo 2'de özetlenmiştir. Bu konuda en geniş serilerde genellikle antibiyotik yüklü çimento kullanılarak yapılan revizyonlarda \%77'ye varan oranlarda başarılı sonuçlar elde edilmiştir.[${ }^{[4]}$ Tek aşamalı revizyon yaklaşımı gram negatif enfeksiyonlarda, akıntılı sinüs ve aktif pürülan enfeksiyon varlığında kontraendikedir. ${ }^{[48]}$

Daha çok kabul gören standart yaklaşım iki aşamaI r revizyon uygulanmasıdır. illk aşamada geniş bir debridman ve irrigasyon uygulanır. Protezin çıkartılmasını takiben boşluk doldurucu (spacer) çimento hazırlanır ve içerisine lokal terapötik amaçla antibiyotik eklenir. [49] Antibiyotikli çimento boşluk doldurucu uygulamasının, iki cerrahi işlem arasında geçen süre zarfında ekstremite uzunluğunu, yumuşak doku gerimini koruması, reimplantasyonu kolaylaştırması ve lokal antibiyotik salınımı sağlaması gibi avantajları bulunmaktadır. ${ }^{[50]}$ Antibiyotikli çimento boşluk doldurucu ameliyathane ortamında cerrah tarafından hazırlanabileceği gibi, ticari olarak üretilmiş hazır formları (PROSTALAC) da mevcuttur. ${ }^{[51]}$ Ayrıca boşluk doldurucular eklemli ve eklemsiz olarak da sınıflandırılır. Uygun uzunluk ve şekil verilmiş eklemli boşluk doldurucular yumuşak doku gerimini ve hareket açılığını korumak suretiyle, ikinci basamak cerrahi sonrası daha iyi bir fonksiyonel sonucu vaat ederler. ${ }^{[52,53]}$ Polimetilmetakrilat boşluk dolduruculara antibiyotik eklenmesi, sadece parenteral antibiyotik uygulamasıyla ulaşılandan çok daha fazla miktarda lokal antibiyotik konsantrasyonu sağlarken; hastanın olası sistemik toksik etkilerden korunması da sağlanır. ${ }^{[53,54]}$

Antibiyotikli çimento uygulamasında seçilen antibiyotik, geniş spektrumlu olmanın yanı sıra çimento polimerizasyonundan etkilenmeyecek derecede ısıya dayanıklı, çevre dokulara ulaşabilmesi için suda-çözünür ve bakterisidal etkisini uzun süreli devam ettirebilmesi için kademeli salınıma uygun olmalıdır. ${ }^{[5,56]}$ En sık kullanılan antibiyotikler gentamisin, tobramisin, vankomisin ve sefalosporinlerdir. ${ }^{[57]}$ Antibiyotikli çimento uygulamasında kullanılacak antibiyotikler için doz standardizasyonu henüz oluşturulmamış olup, değişik merkezlerin farklı doz uygulamaları mevcuttur. Hacettepe çalışmasında, enfekte hastalardan elde edilen klinik suşlar üzerine değişik antibiyotik kombinasyonlu çimento boşluk doldurucuların etkisi karşılaştırıldı. $4 \mathrm{~g}$ vankomisinli kemik çimentosu \%90, gentamisinli kemik çimentosu \%85, $1 \mathrm{~g}$ vankomisinli kemik çimentosu $\% 77,5$, borik asit ve $1 \mathrm{~g}$ vankomisinli kemik çimentosu da \%77,5 etkin bulunurken, tek başına kemik

Tablo 2. Tek aşamalı revizyon cerrahisi için aranan kriterler

- Etken mikro-organizma antibiotiklere karşı hassas olmalı ve izole edilmelidir.

- Konak nispeten sağlıklı olmalı ve romatoid artrit, diyabet, kronik cilt lezyonları ve obezite gibi risk faktörleri içermemelidir.

- Cilt ve skar dokusu, yumuşak doku sağlıklı olarak kapanabilmelidir. 
çimentosunun ve borik asitli kemik çimentosunun etkinliği \%0 olarak tespit edildi. Stafilokoklar üzerinde $1 \mathrm{~g}$ vankomisinli ve $4 \mathrm{~g}$ vankomisinli çimentolar \%100 etkinlik gösterirken gentamisinli çimento \%84,2 etkinlik gösterdi. Gram negatif basillere gentamisinli çimentonun etkinliği \%66,6 ve $4 \mathrm{~g}$ vankomisinli çimentonun etkinliği \%33,3 bulunurken, $1 \mathrm{~g}$ vankomisinli çimentonun etkinliği $\% 0$ olarak bulundu. ${ }^{[58]}$

Antibiyotikli çimento boşluk doldurucudan antibiyotik salınımı birçok faktöre bağlıdır. Salınım yüzey alanı arttıkça salınım miktarı da artar. ${ }^{[59]}$ Antibiyotiğin tipi ve miktarı salınımı etkiler. Antibiyotiklerin kombine edilmesi sinerjistik etkiyle salınımlarını arttırabilir. ${ }^{[60]}$ Çimentonun viskozitesi ve porozitesi de antibiyotik salınımını etkilemektedir. Yapılan bir çalışmada, Palacos marka çimentonun, Simplex'e göre daha iyi antibiyotik salınımı sağladığı belirtilmektedir. ${ }^{[61]}$ Çimento porozitesini artıran durumlar da antibiyotik salınımını artırır. ${ }^{[62]}$
Burada iki aşama arasında 6 hafta boyunca i.v antibiotik uygulanması ve bu dönemde enfeksiyon belirteçlerinin takibi esastır.

Yazarlar arasında $10 \mathrm{~g}$ vankomisin ile 12 g gentamisin dozuna kadar güvenli olduğunu söyleyenler olduğu gibi, akut böbrek yetmezliği ve antibiyotik toksisitesine bağlı kaybedilen hasta rapor eden yayınlarda mevcuttur. ${ }^{[63,64]}$

Hacettepe enfekte total kalça artroplastisi revizyon serisinde; sistemik toksisiteden kaçınmak amacıyla uyguladığımız düşük doz vankomisinli çimento $(1 \mathrm{~g}$ ( $40 \mathrm{~g}$ ) ile yapılan iki aşamalı enfekte total kalça protezi tedavisinde 4 yılda \% 94,12 sağkalım sağlamıştır. Literatürde belirtilenden daha düşük dozda ilaç kullanımı ile olası toksik etkilerden kaçınılırken aynı zamanda da etkin tedavi yapılabildiğini göstermesi açısından bu deneyimin önemli olduğunu düşünüyoruz (Şekil 1).
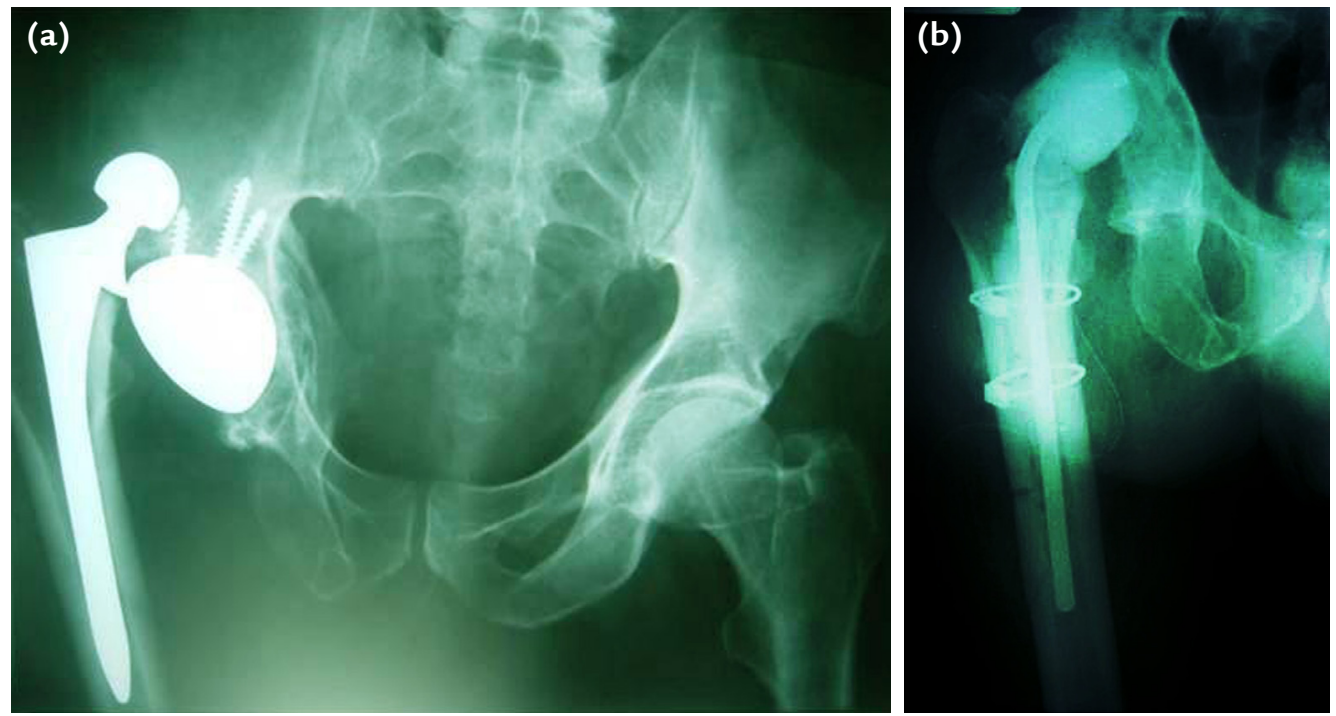

Şekil 1. a-c. 50 yaşında erkek hasta. Sağ total kalça protezi dislokasyonu ile acil servise başvuran hastanın yapılan tetkiklerinde enfeksiyon saptandı (a). Hastaya geniş derbridmanı takiben protezi çıkartılarak el yapımı antibiyotik emdirilmiş boşluk doldurucu yerleştirildi (b). 6 haftalık parenteral antibiyotik tedavi uygulanan hastaya enfeksiyon eradikasyonunu takiben 2. basamak revizyon cerrahisi uygulandı (c).

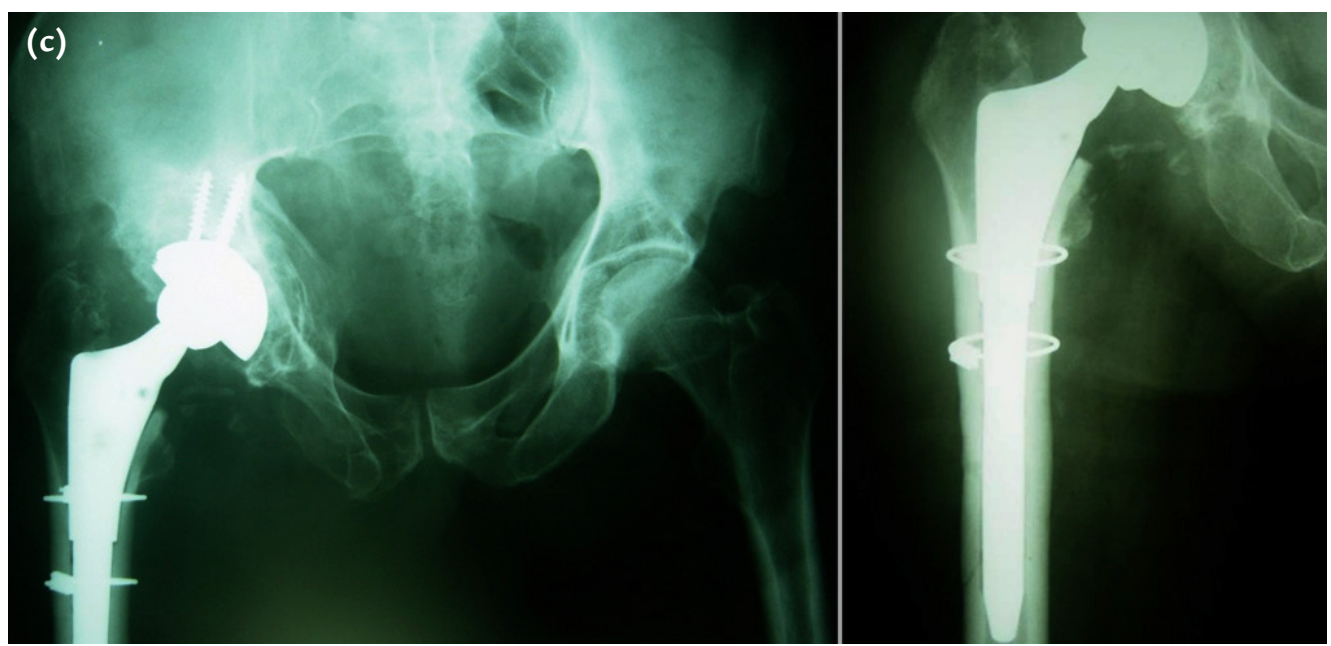


Diğer bir tartışma konusu ise ikinci basamak cerrahisindeki tespitin tipidir. Geçmişte çimentolu sistemler altın standart olarak kabul görmekte iken, günümüzde daha az gevşeme oranları sağlayan çimentosuz sistemler daha ön plandadır. Kemik defektlerinin allogreft ile doldurulması yaklaşımı tartışmalı bir konu olmakla birlikte, literatürde re-enfeksiyon riskini arttırmadığına dair çalışmalar mevcuttur. ${ }^{[65]}$

Sonuç olarak, total kalça artroplastisinin klinik başarısını en fazla etkileyen enfeksiyon sorunundan kaçınmak için uygun hasta seçimi, uygun ameliyat öncesi değerlendirme ve başta uygun antibiyotik kullanımı olmak üzere profilaktik yöntemlerin hasta yararına kullanılması çok önemlidir. Bir kez enfeksiyon oluştu mu, kestirme yolar başarılı olamamakta ve hastalar sıkıntılı tedavi süreçlerinden, tekrarlayan ameliyatlardan geçmek zorunda kalmakta, toplum içinse yüksek ekonomik maliyetler söz konusu olmaktadır. Kronik enfeksiyonların tedavisinde iki aşamalı revizyon tedavisi \%90-100 eradikasyon oranlarına sahip olmanın yanında, yüksek fonksiyon ve hasta memnuniyeti sağlaması ve hastanede yatış süresi ve maliyeti azaltması nedeniyle günümüzde altın standart yaklaşım olarak kabul görmelidir. ${ }^{[66,67]}$

\section{KAYNAKLAR}

1. Charnley J. Postoperative infection after total hip replacement with special reference to air contamination in the operating room. Clin Orthop Relat Res 1972;87:167-87.

2. Salvati EA, Wilson PD Jr, Jolley MN, Vakili F, Aglietti P, Brown GC. A ten-year follow-up study of our first one hundred consecutive Charnley total hip replacements. J Bone Joint Surg Am1981;63(5):753-67.

3. Ulrich SD, Seyler TM, Bennett D, Delanois RE, Saleh KJ, Thongtrangan I, Kuskowski M, Cheng EY, Sharkey PF, Parvizi J, Stiehl JB, Mont MA. Total hip arthroplasties: what are the reasons for revision? Int Orthop 2008 October;32(5):597-604.

4. Hanssen DA, Rand JA. Evaluation and treatment of infection at the site of a total hip or knee arthroplasty. Instr Course Lect 1999;48:111-22.

5. Poss R, Thornhill TS, Ewald FC, Thomas WH, Batte NJ, Sledge $C B$. Factors influencing the incidence and outcome of infection following total joint arthroplasty. Clin Orthop Relat Res 1984;(182):117-26.

6. Wilson MG, Kelley, K, Thornhill, TS. Infection as a complication of total knee-replacement arthroplasty. Risk factors and treatment in sixty-seven cases. J Bone Joint Surg Am 1990;72(6):878-83.

7. Menon TJ, Thjellesen D, Wroblewski BM. Charnley lowfriction arthroplasty in diabetic patients. J Bone Joint Surg $\mathrm{Br}$ 1983;65(5):580-1.

8. Smith TK. Nutrition: its relationship to orthopedic infections. Orthop Clin North Am 1991;22(3):373-7.

9. Gherini S, Vaughn BK, Lombardi AV Jr, Mallory TH. Delayed wound healing and nutritional deficiencies after total hip arthroplasty. Clin Orthop Relat Res 1993;(293):188-95.

10. Stern SH, Insall JN, Windsor RH, Inglis AE, Dines DM. Total knee arthroplasty in patients with psoriasis. Clin Orthop Relat Res 1989;(248):108-10; discussion 111.
11. Surin W, Sundholm K, Bäckman L. Infection after total hip replacement. With special reference to a discharge from the wound. J Bone Joint Surg Br 1983;65(4):412-8.

12. Schmalzried TP, Amstutz HC, Au MK, Dorey FJ. Etiology of deep sepsis in total hip arthroplasty. The significance of hematogenous and recurrent infections. Clin Orthop Relat Res 1992;(280):200-7.

13. Brown AR, Taylor GJS, Gregg PJ. Air contamination during skin preparation and draping in joint replacement surgery. J Bone Joint Surg Br 1996;78(1):92-4.

14. Schutzer SF, Harris WH. Deep-wound infection after total hip replacement under contemporary aseptic conditions. J Bone Joint Surg Am 1988;70(5):724-7.

15. Ritter MA, Eitzen HE, French ML, Hart JB. The effect that time, touch and environment have upon bacterial contamination of instruments during surgery. Ann Surg 1976;184(5):642-4.

16. Ritter MA, Eitzen HE, Hart JB, French ML. The surgeon's garb. Clin Orthop Relat Res 1980;(153):204-9.

17. Blomgren G, Hoborn J, Nyström B. Reduction of contamination at total hip replacement by special working clothes. J Bone Joint Surg Br 1990;72(6):985-7.

18. Johnston DH, Fairclough JA, Brown EM, Morris R. Rate of bacterial recolonization of the skin after preparation: four methods compared. British J Surg 1987;74(1):64.

19. Lowell JD, Kundsin RB, Schwartz CM, Pozin D. Ultraviolet radiation and reduction of deep wound infection following hip and knee arthroplasty. Ann N Y Acad Sci 1980;353:285-93.

20. Patzakis MJ, Wilkins J. Factors influencing infection rate in open fracture wounds. Clin Orthop Relat Res 1989;(243):36-40.

21. Fletcher $\mathrm{N}$, Sofianos $\mathrm{D}$, Berkes MB, Obremskey WT. Prevention of perioperative infection. J Bone Joint Surg Am 2007;89(7):1605-18.

22. Atilla B, Tokgözoğlu AM, Ayvaz M, Akgün R, Alpaslan AM. Low dose vancomycin impregnated cement spacers are effective in two stage hip revision protocol. Hip Society; 8th Domestic Meeting Madrid 2008.

23. Petty W, Spanier S, Shuster JJ, Silverthorne C. The influence of skeletal implants on incidence of infection. Experiments in a canine model. J Bone Joint Surg Am 1985;67(8):1236-44.

24. Gristina AG. Implant failure and the immuno-incompetent fibro-inflammatory zone. Clin Orthop Relat Res 1994;(298):106-18.

25. Gristina AG. Biomaterial-centered infection: microbial adhesion versus tissue integration. Science 1987;237(4822):1588-95.

26. Gristina AG, Costerton JW. Bacterial adherence to biomaterials and tissue. The significance of its role in clinical sepsis. J Bone Joint Surg Am 1985; 67(2):264-73.

27. Tsukayama DT, Goldberg VM, Kyle R. Diagnosis and management of infection after total knee arthroplasty. J Bone Joint Surg Am 2003;85A Suppl 1:S75-80.

28. Nelson JP, Glassburn AR Jr, Talbott RD, McElhinney JP. The effect of previous surgery, operating room environment, and preventive antibiotics on postoperative infection following total hip arthroplasty. Clin Orthop Relat Res 1980;(147):167-9.

29. Schmalzried TP, Amstutz HC, Au MK, Dorey FJ. Etiology of deep sepsis in total hip arthroplasty. The significance of hematogenous and recurrent infections. Clin Orthop Relat Res 1992;(280):200-7.

30. Fitzgerald $\mathrm{RH}$ Jr. Total hip arthroplasty sepsis. Prevention and diagnosis. Orthop Clin North Am 1992;23(2):259-64.

31. Hanssen AD, Osmon DR, Nelson CL. Prevention of deep periprosthetic joint infection. Instr Course Lect 1997;46:555-67. 
32. Levitsky KA, Hozack WJ, Balderston RA, Rothman RH, Gluckman SJ, Maslack MM, Booth RE Jr. Evaluation of the painful prosthetic joint. Relative value of bone scan, sedimentation rate, and joint aspiration. J Arthroplasty 1991;6(3):237-44.

33. Greidanus NV, Masri BA, Garbuz DS, Wilson SD, McAlinden MG, Xu M, Duncan CP. Use of erythrocyte sedimentation rate and $\mathrm{C}$-reactive protein level to diagnose infection before revision total knee arthroplasty. A prospective evaluation. J Bone Joint Surg Am 2007;89(7):1409-16.

34. Bottner F, Wegner A, Winkelmann W, Becker K, Erren M, Götze C. Interleukin-6, procalcitonin and TNF-alpha: markers of periprosthetic infection following total joint replacement. J Bone Joint Surg Br 2007;89(1):94-9.

35. Di Cesare PE, Chang E, Preston CF, Liu CJ. Serum interleukin-6 as a marker of periprosthetic infection following total hip and knee arthroplasty. J Bone Joint Surg Am 2005;87(9):1921-7.

36. Rand JA, Brown ML. The value of indium 111 leukocyte scanning in the evaluation of painful or infected total knee arthroplasties. Clin Orthop Relat Res 1990;(259):179-82.

37. Palestro CJ, Kim CK, Swyer AJ, Capozzi JD, Solomon RW, Goldsmith SJ. Total hip arthroplasty: periprosthetic indium111-labeled leukocyte activity and complementary technetium$99 \mathrm{~m}$-sulfur colloid imaging in suspected infection. J Nucl Med 1990;31(2):1950-5.

38. Mumme T, Reinartz $P$, Alfer J, Müller-Rath R, Buell $U$, Wirtz DC. Diagnostic values of positron emission tomography versus triple-phase bone scan in hip arthroplasty loosening. Arch Orthop Trauma Surg 2005;125(5):322-9.

39. Chimento GF, Finger S, Barrack RL. Gram stain detection of infection during revision arthroplasty. J Bone Joint Surg $\mathrm{Br}$ 1996;78(5):838-9.

40. Barrack RL, Harris WH. The value of aspiration of the hip joint before revision total hip arthroplasty. J Bone Joint Surg Am 1993;75(1):66-76.

41. Schinsky MF, Della Valle DJ, Sporer SM, Paprosky WG. Perioperative testing for joint infection in patients undergoing revision total hip arthroplasty. J Bone Joint Surg Am 2008;90(9):1869-75. CrossRef

42. Athanasou NA, Pandey R, de Steiger R, Crook D, McLardy Smith PM. Diagnosis of infection by frozen section during revision arthroplasty. J Bone Joint Surg Br 1995;77(1):28-33.

43. Pandey R, Berendt AR, Athanasou NA. Histological and microbiological findings in non-infected and infected revision arthroplasty tissues. The OSIRIS Collaborative Study Group. Oxford Skeletal Infection Research and Intervention Service. Arch Orthop Trauma Surg 2000;120(10):570-4.

44. Abdul-Karim FW, McGinnis MG, Kraay M, Emancipator SN, Goldberg V. Frozen section biopsy assessment for the presence of polymorphonuclear leukocytes in patients undergoing revision of arthroplasties. Mod Pathol 1998;11(5):427-31.

45. Banit DM, Kaufer H, Hartford JM. Intraoperative frozen section analysis in revision total joint arthroplasty. Clin Orthop Relat Res 2002;(401):230-8.

46. Hanssen AD, Spangehl MJ. Treatment of the infected hip replacement. Clin Orthop Relat Res 2004;(420):63-71.

47. Tsukayama DT, Goldberg VM, Kyle R. Diagnosis and management of infection after total knee arthroplasty. J Bone Joint Surg Am 2003;85-A Suppl 1:S75-80.

48. Buchholz HW, Elson RA, Engelbrecht E, Lodenkämper $H$, Röttger J, Siegel A. Management of deep infection of total hip replacement. J Bone Joint Surg Br 1981;63-B(3):342-53.

49. Hsieh $\mathrm{PH}$, Chen $\mathrm{LH}$, Chen $\mathrm{CH}$, Lee MS, Yang WE, Shih $\mathrm{CH}$. Two-stage revision hip arthroplasty for infection with a custom-made, antibiotic-loaded, cement prosthesis as an interim spacer. J Trauma 2004;56(6):1247-52.
50. Garvin KL, Hanssen AD. Infection after total hip arthroplasty. Past, present, and future. J Bone Joint Surg Am 1995;77(10):1576-88.

51. Wentworth SJ, Masri BA, Duncan CP, Southworth CB. Hip prosthesis of antibiotic-loaded acrylic cement for the treatment of infections following total hip arthroplasty. J Bone Joint Surg Am 2002;84-A Suppl 2:123-8.

52. Durbhakula SM, Czajka J, Fuchs MD, Uhl RL. Spacer endoprosthesis for the treatment of infected total hip arthroplasty. J Arthroplasty 2004;19(6):760-7.

53. Barrack RL. Rush pin technique for temporary antibioticimpregnated cement prosthesis for infected total hip arthroplasty. J Arthroplasty 2002;17(5):600-3.

54. Springer BD, Lee GC, Osmon D, Haidukewych GJ, Hanssen $A D$, Jacofsky DJ. Systemic safety of high-dose antibioticloaded cement spacers after resection of an infected total knee arthroplasty. Clin Orthop Relat Res 2004;(427):47-51.

55. Hanssen AD, Spangehl MJ. Practical applications of antibiotic-loaded bone cement for treatment of infected joint replacements. Clin Orthop Relat Res 2004;(427):79-85.

56. Koo KH, Yang JW, Cho SH, Song HR, Park HB, Ha YC, Chang JD, Kim SY, Kim YH. Impregnation of vancomycin, gentamicin, and cefotaxime in a cement spacer for two-stage cementless reconstruction in infected total hip arthroplasty. J Arthroplasty 2001;16)7):882-92.

57. Joseph TN, Chen AL, Di Cesare PE. Use of antibioticimpregnated cement in total joint arthroplasty. J Am Acad Orthop Surg 2003;11(1):38-47.

58. Batmaz G. Protez çevresi enfeksiyonlarından elde edilen klinik suşlar üzerinde geçici dolgu içerisindeki düşük doz vankomisinin, gentamisinin ve borik asitin in vitro etkinliği. Uzmanlık tezi 2012

59. Greene N, Holtom PD, Warren CA, Ressler RL, Shepherd L, McPherson EJ, Patzakis MJ. In vitro elution of tobramycin and vancomycin polymethylmethacrylate beads and spacers from Simplex and Palacos. Am J Orthop (Belle Mead NJ) 1998;27(3):201-5.

60. Masri BA, Duncan CP, Beauchamp CP. Long-term elution of antibiotics from bone-cement: an in vivo study using the prosthesis of antibiotic-loaded acrylic cement (PROSTALAC) system. J Arthroplasty 1998;13(3):331-8.

61. Stevens CM, Tetsworth KD, Calhoun JH, Mader JT. An articulated antibiotic spacer used for infected total knee arthroplasty: a comparative in vitro elution study of Simplex and Palacos bone cements. J Orthop Res 2005;23(1):27-33.

62. Kuehn KD, Ege W, Gopp U. Acrylic bone cements: composition and properties. Orthop Clin North Am 2005;36(1):17-28, v.

63. Alt V, Bitschnau A, Osterling J, Sewing A, Meyer C, Kraus $R$, Meissner SA, Wenisch S, Domann E, Schnettler R. The effects of combined gentamicin-hydroxyapatite coating for cementless joint prostheses on the reduction of infection rates in a rabbit infection prophylaxis model. Biomaterials 2006;27(26):4627-34.

64. Evans RP. Successful treatment of total hip and knee infection with articulating antibiotic components: a modified treatment method. Clin Orthop Relat Res 2004;(427):37-46.

65. Alexeeff M. Mahomed N, Morsi H, Garbuz D, Gross A. Structural allograft in two-stage revisions for failed septic hip arthroplasty. J Bone Joint Surg Br 1996;78(2):213-6.

66. Meek RM, Masri BA, Dunlop D, Garbuz DS, Greidanus NV, McGraw R, Duncan CP. Patient satisfaction and functional status after treatment of infection at the site of a total knee arthroplasty with use of the PROSTALAC articulating spacer. J Bone Joint Surg Am 2003;85-A(10):1888-92.

67. Younger AS, Duncan CP, Masri BA, McGraw RW. The outcome of two-stage arthroplasty using a custom-made interval spacer to treat the infected hip. J Arthroplasty 1997;12(6):615-23. 